\title{
Penerapan Metode Bermain Peran sebagai Upaya untuk Meningkatkan Perkembangan Sosial Emosional Peserta Didik
}

\author{
Hikmawati ${ }^{1}$, Takasun², Luk Luk Ul Hikmah \\ ${ }^{1}$ Pendidikan Fisika, FKIP, Universitas Mataram, Mataram, Indonesia \\ 2 TK Rinjani DW Universitas Mataram, Mataram, Indonesia \\ ${ }^{3}$ TK Mustika Rini Karangnongko, Jepara, Indonesia
}

DOI: $\underline{10.29303 / \text { ujcs.v2i4.161 }}$

\section{Article Info}

Received: November 25, 2021

Revised: Desember 27, 2021

Accepted: Desember 29, 2021

\begin{abstract}
Abstrak: Tujuan kegiatan pengabdian kepada masyarakat ini adalah menerapkan metode bermain peran sebagai upaya untuk meningkatkan perkembangan sosial emosional peserta didik. Kegiatan dilaksanakan pada tanggal 17 November 2021 di TK Mustika Rini Karangnongko dengan jumlah peserta sebanyak 8 orang. Metode kegiatan terdiri atas 3 tahapan yaitu persiapan, pelaksanaan, dan refleksi. Hasil kegiatan untuk setiap tahapan yaitu: pada tahap persiapan, tim menyiapkan alat dan bahan, dan membimbing peserta didik melakukan berbagai aktivitas sehingga siap untuk bermain peran. Pada tahap pelaksanaan, tim membimbing peserta didik melakukan tiga jenis kegiatan. Kegiatan 1: Membuat mozaik bentuk ayam dari cangkang telur. Kegiatan 2: Memecahkan telur dan menggoreng telur menjadi sate telur gulung. Kegiatan 3: Bermain peran menjadi penjual dan pembeli sate telur gulung. Pada tahap refleksi, dilakukan recalling dan rencana tindak lanjut. Aspek yang dinilai untuk perkembangan sosial emosional peserta didik pada kegiatan bermain peran ini adalah keberanian, percaya diri, kemandirian, dan komunikasi. Perkembangan sosial emosional peserta didik yaitu peserta didik mampu bermain peran menjadi penjual dan pembeli telah Berkembang Sesuai Harapan (BSH).

Kata Kunci: Metode bermain peran; perkembangan sosial emosional.

Abstract: The purpose of this community service activity is to apply the role-playing method as an effort to improve the socioemotional development of students. The activity was held on November 17, 2021 at Mustika Rini Karangnongko Kindergarten with a total of 8 participants. The activity method consists of 3 stages, namely preparation, implementation, and reflection. The results of the activities for each stage are: in the preparation stage, the team prepares tools and materials, and guides students to carry out various activities so that they are ready to play roles. At the implementation stage, the team guides students to do three types of activities. Activity 1: Make a chicken-shaped mosaic from egg shells. Activity 2: Cracking eggs and frying eggs into egg rolls. Activity 3: Role-play being a seller and buyer of egg rolls. At the reflection stage, a recall and follow-up plan are carried out. Aspects that are assessed for the social emotional development of students in this role-playing activity are courage, self-confidence, independence, and communication. The socio-emotional development of students, namely students who are able to play the role of being a seller and a buyer, has developed according to expectations (BSH).

Keywords: Role playing method; emotional social development.
\end{abstract}

Citation: Hikmawati, H., Takasun, T., \& Hikmah, L.L.U. (2021). Penerapan Metode Bermain Peran sebagai Upaya untuk Meningkatkan Perkembangan Sosial Emosional Peserta Didik. Unram Journal of Community Service, 2(4), 116-121.

https://doi.org/10.29303/ujcs.v2i4.161

\section{Pendahuluan}

Anak usia dini merupakan individu unik yang berada pada rentang usia nol sampai dengan enam tahun. Setiap individu memiliki tahapan perkembangan tertentu sesuai dengan perkembangan usianya. Kegiatan yang dapat menstimulus perkembangan anak yaitu bermain. Dengan bermain, dapat memberikan rangsangan dan membuat anak merasa senang sehingga dapat memberikan

\footnotetext{
*Email: hikmawati@unram.ac.id
} 
kesempatan kepada anak untuk bergerak aktif serta dapat berinteraksi dengan lingkungannya dan mengendalikan emosinya dengan wajar. Salah satu metode bermain yang dapat dilakukan untuk mengembangkan sosial emosional anak yaitu metode bermain peran (Oktaviana et al., 2021).

Banyak orang tua, guru dan masyarakat menganggap bahwa Taman Kanak-kanak merupakan lembaga yang hanya menyiapkan anak masuk Sekolah Dasar. Hal tersebut menyebabkan proses pembelajaran sebatas pengembangan kemampuan membaca, menulis dan menghitung, sehingga kesempatan meningkatkan kemampuan sosial emosional anak terabaikan. Kemampuan sosial emosional pada anak perlu digali dan ditumbuhkembangkan dengan cara memperbaiki materi dan metode pembelajaran yang diberikan guru. Bermain peran merupakan metode pembelajaran yang memberikan kesempatan anak untuk mengembangkan imajinasinya, serta berlatih bersosialisasi, berkomunikasi dan berempati dengan anak-anak lain (Bakri et al., 2021).

Rendahnya nilai keterampilan sosial serta emosional peserta didik dapat diatasi dengan menggunakan metode bermain peran. Salah satu caranya adalah bermain peran sebagai penjual atau pembeli dalam suatu aktivitas jual-beli. Dengan kegiatan bermain peran, imajinasi anak berperan sesungguhnya dan menjadi seseorang atau sesuatu, yang didapatkan dari pengalaman sehari-hari yang anak temui. Manfaat dalam bermain peran diantaranya adalah dapat menunjang pengembangan diri bagi anak karena anak akan mampu mandiri dalam berinteraksi sosial dengan orang disekitarnya (Halifah, 2020). Terdapat perbedaan antara metode bermain peran terhadap perkembangan sosial emosional anak dalam perilaku prososial dengan metode konvensional terhadap perkembangan sosial emosional anak dalam perilaku prososial pada anak kelompok B (Dewi et al., 2017).

Pengembangan sosial-emosional peserta didik pada usia dini bertujuan untuk mencapai optimalisasi semua aspek perkembangan peserta didik baik perkembangaan fisik maupun psikis, yaitu intelektual, bahasa, motorik, dan sosio emosional, lewat kegiatan yang menyenangkan dan sesuai dengan tuntutan dan harapan sosial yang berlaku di masyarakat (Jamilah, 2019). Apabila peserta didik yang melaksanakan aktivitas bermain peran terlihat antusias dan gembira, maka akan dapat berdampak positif bagi peserta didik dalam meningkatkan keterampilan sosial dan kecerdasan emosionalnya (Mangkuwibawa \& Kurnia, 2021).

Bermain secara kelompok memberikan peluang dan pelajaran kepada anak untuk berinteraksi, bertenggang rasa dengan sesama teman. Untuk itu sebagai usaha menanamkan dan mengembangkan karakter peserta didik di sekolah dapat dikembangkan melalui metode pembelajaran bermain peran (Rantauwati, 2014).

Perkembangan sosial-emosional peserta didik yang dapat diamati melalui penerapan metode bermain peran di kelas adalah: Menunjukan sikap partisipasi, komunikasi dan interaksi; Mampu menyesuaikan diri dengan kelompok belajar; Menunjukan rasa percaya diri. Penerapan metode bermain peran untuk meningkatkan perkembangan sosial-emosional siswa di luar pembelajaran dapat ditunjukkan dengan hal-hal seperti: sikap membantu teman lain saat membutuhkan pertolongan, tidak memaksakan kehendak sendiri, mampu menyelesaikan masalah saat bermain, dapat mengontrol emosi saat bermain. Upaya guru dalam mengembangkan sosial-emosional peserta didik melalui metode bermain peran yaitu sebagai berikut: menciptakan hubungan perkembangan sosialemosional yang baik terhadap siswa, bersikap sebagai figur yang harus dicontoh oleh siswa, memberikan bimbingan, arahan, untuk mendorong tercapainya perkembangan sosial-emosional (Tusyana et al., 2019).

Berdasarkan hasil pengamatan di TK Mustika

Rini Karangnongko, terdapat kesenjangan antara tingginya aktivitas bermain peran dengan rendahnya keterampilan sosial dan kecerdasan emosional pada sebagian peserta didik. Hal ini ditunjukkan dengan adanya sebagian peserta didik yang sikap sosialnya masih kurang dan peserta didik masih kurang dalam mengenali serta mengelola emosionalnya. Tujuan kegiatan pengabdian kepada masyarakat ini adalah menerapkan metode bermain peran sebagai upaya untuk meningkatkan perkembangan sosial emosional peserta didik di TK Mustika Rini Karangnongko.

\section{Metode}

Metode kegiatan pengabdian kepada masyarakat ini terdiri atas 3 tahapan yaitu persiapan, pelaksanaan, dan refleksi. Hasil kegiatan untuk setiap tahapan yaitu: pada tahap persiapan, tim menyiapkan alat dan bahan, dan membimbing peserta didik melakukan berbagai aktivitas sehingga siap untuk bermain peran. Pada tahap pelaksanaan, tim membimbing peserta didik melakukan tiga jenis kegiatan. Kegiatan 1: Membuat mozaik bentuk ayam dari cangkang telur. Kegiatan 2: Memecahkan telur dan menggoreng telur menjadi sate telur gulung. Kegiatan 3: Bermain peran menjadi penjual dan pembeli sate telur gulung. Pada tahap refleksi, dilakukan recalling dan rencana tindak lanjut. Aspek yang dinilai untuk perkembangan sosial emosional peserta didik pada kegiatan bermain peran 
ini adalah keberanian, percaya diri, kemandirian, dan komunikasi.

\section{Hasil dan Pembahasan}

Pada tahap Persiapan, hal-hal yang dilakukan adalah tim menyiapkan alat dan bahan yang akan digunakan, dan membimbing peserta didik melakukan berbagai aktivitas sehingga siap untuk bermain peran. Aktivitas yang dimaksud yaitu: Senam bersama; Berdoa sebelum kegiatan belajar; Menyapa anak dengan nyanyian selamat pagi; Bertepuk tangan (tepuk semangat); Anak menyebutkan hewan yang berkaki dua salah satunya ayam; Guru mengajak anak untuk menonton video tentang perkembangbiakan ayam; Menirukan Gerakan melalui bernyanyi ayam dan bebek; Guru mengajak anak untuk mengamati anak ayam; dan Penguatan motorik kasar. Dokumentasi untuk tahap persiapan ditunjukkan Gambar 1 dan Gambar 2.

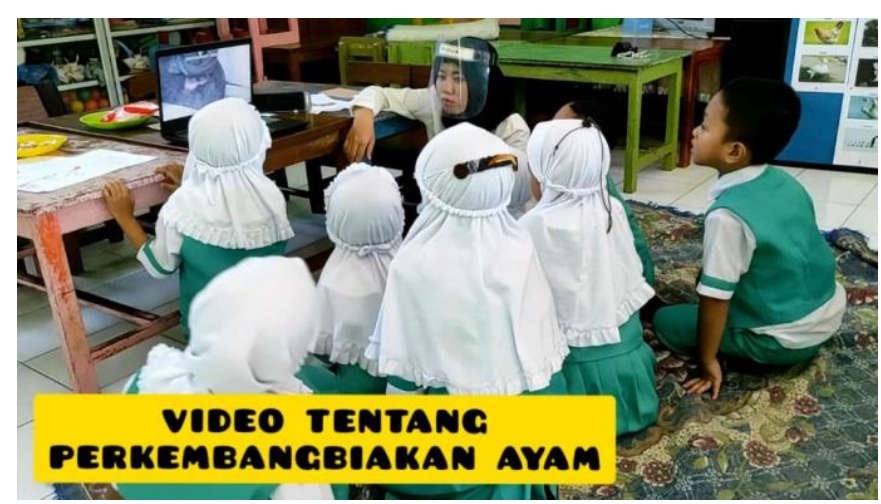

Gambar 1. Apresepsi perkembangbiakan ayam.

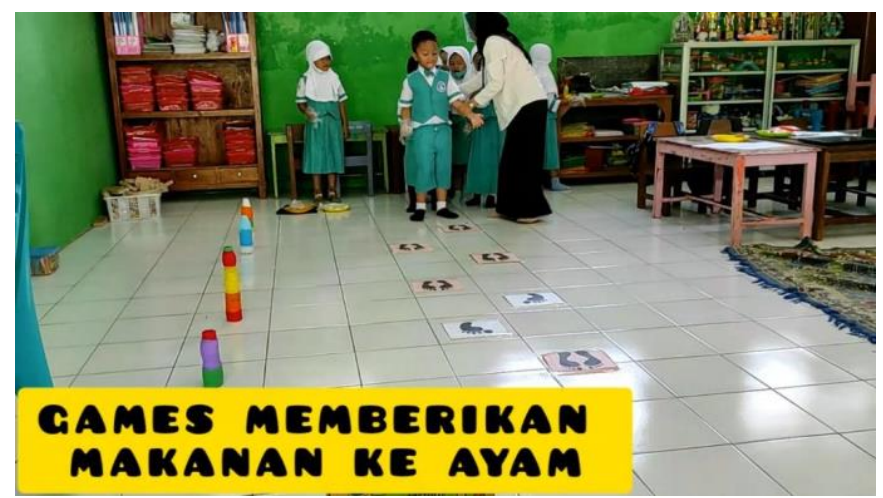

Gambar 2. Penguatan motorik kasar

Pada tahap pelaksanaan, tim membimbing peserta didik melakukan tiga jenis kegiatan. Kegiatan 1: Membuat mozaik bentuk ayam dari cangkang telur. Langkah-langkahnya adalah: Guru menyiapkan LKPD gambar ayam; Anak menempelkan pecahan cangkang telur dengan lem; Anak menempelkan sesuai pola gambar ayam sehingga anak menghasilkan karya mozaik ayam. Dokumentasi membuat mozaik ayam dengan menggunakan cangkang telur ditunjukkan Gambar 3.

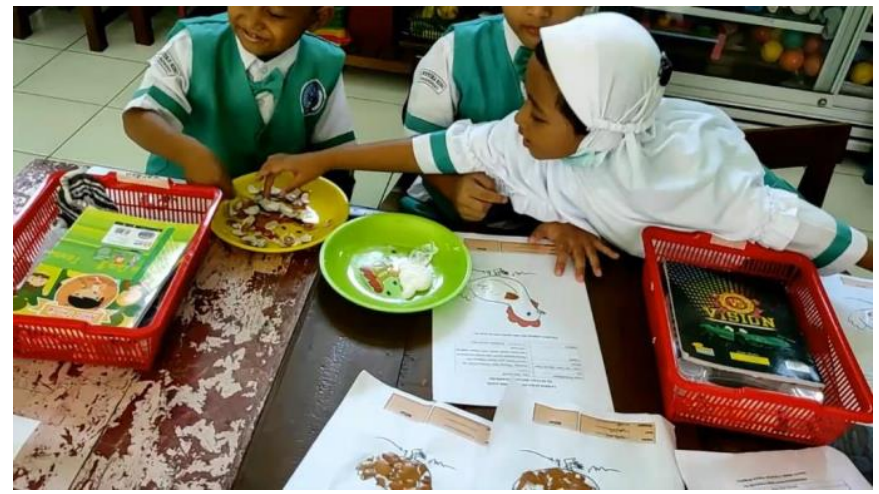

Gambar 3. Membuat Mozaik ayam

Kegiatan 2: Memecahkan telur dan menggoreng telur menjadi sate telur gulung. Langkah-langkahnya adalah: Guru menyiapkan bahan dan alat; Anak memakai celemek; Anak memecahkan telur ayam ke dalam mangkok; Anak memecahkan telur puyuh; Anak mengkocok telur; Anak menggoreng telur menjadi sate telur gulung. Dokumentasi kegiatan memasak sate telur gulung ditunjukkan Gambar 4.

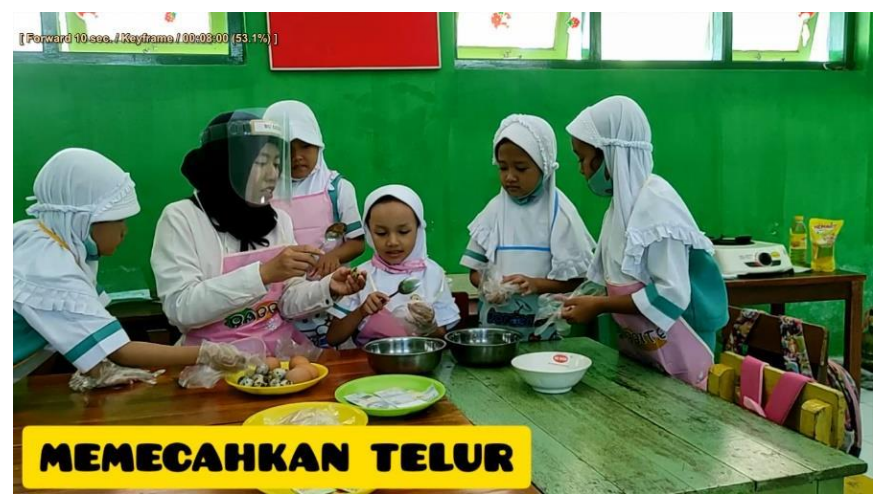

Gambar 4. Kegiatan memasak sate telur gulung

Kegiatan 3: Bermain peran menjadi penjual dan pembeli sate telur gulung. Langkah-langkahnya adalah: Menyiapkan beberapa sate telur gulung dalam wadah; Menyiapkan uang mainan untuk membeli sate telur gulung; Guru menentukan siapa yang mau jadi penjual dan pembeli; Anak yang mau jadi penjual dipakaikan celemek; Anak yang mau jadi pembeli mengantri untuk membeli; Bermain peran menjadi penjual dan pembeli sesuai karakter masing-masing. Dokumentasi kegiatan bermain peran ditunjukkan Gambar 5. 


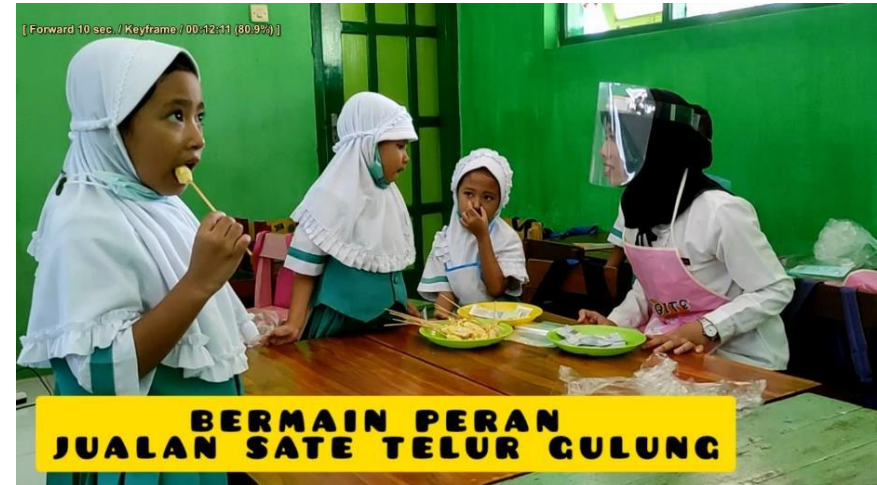

Gambar 5. Kegiatan Bermain peran jual beli

Pada tahap refleksi, dilakukan recalling dan rencana tindak lanjut. Kegiatan yang dilakukan yaitu: Merapikan alat-alat yang telah digunakan; Diskusi tentang perasaan diri selama melakukan kegiatan bermain; Bila ada perilaku yang kurang tepat harus didiskusikan Bersama; Menceritakan dan menunjukkan hasil karyanya; Penguatan pengetahuan yang didapat anak. Dokumentasi kegiatan recalling ditunjukkan Gambar 6.

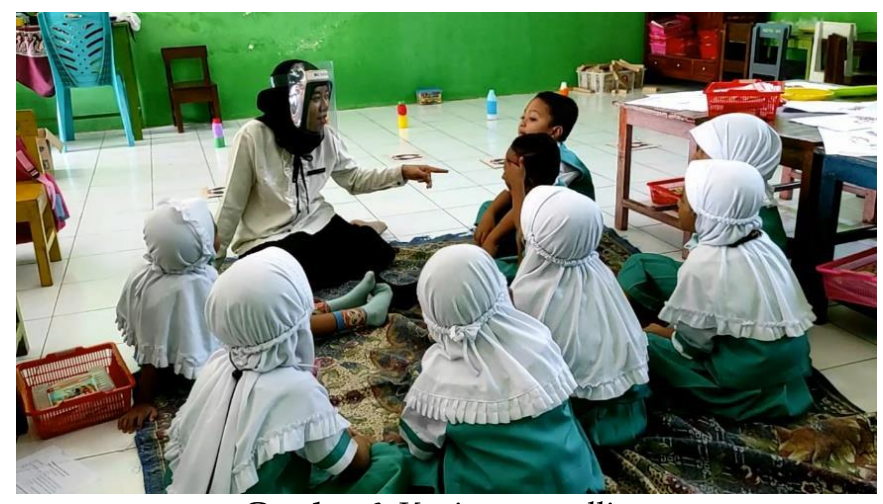

Gambar 6. Kegiatan recalling

Anak usia prasekolah merupakan masa bermain, metode yang digunakan sebaiknya yang mengandung unsur bermain, seperti bermain peran. Metode bermain peran memiliki dampak yang baik terhadap peningkatan perkembangan sosial anak (Engga et al., 2017). Aspek yang dinilai untuk perkembangan sosial emosional peserta didik pada kegiatan bermain peran ini adalah keberanian, percaya diri, kemandirian, dan komunikasi.

Kemampuan komunikasi merupakan bentuk pengembangan yang menitikberatkan pada aspek bahasa. Dalam kegiatan bermain peran terdapat beberapa aktifitas yang dapat meningkatkan kemampuan aspek bahasa ekspresif anak yaitu: interaksi, imajinasi, percaya diri. Interaksi, dalam hal ini anak-anak diarahkan untuk melakukan proses interaksi sehingga anak akan memperoleh kosa kata baru yang bermanfaat dalam kegiatan berbahasa lisan anak. Imajinasi, merupakan salah satu dari kelebihan dalam kegiatan bermain peran. Anak tidak harus melakukan kegiatan menghafal kata-kata sebagaimana bentuk dari pelaksanaan pembelajaran konvensional. Metode bermain peran mengajarkan kepada anak untuk berimajinasi dalam memerankan peran sehingga anak dapat mengungkapkan ide. Bermain peran dapat memupuk rasa percaya diri. Walaupun dalam meningkatkan keberanian dan rasa percaya diri kepada anak bukanlah hal yang mudah. Melalui kegiatan bermain peran, keberanian dan rasa percaya diri anak dapat dipupuk apabila kegiatan ini dilakukan secara berulang-ulang tidak hanya dengan sekali bermain ataupun sekali pertemuan saja. Dengan meningkatnya keberanian dan rasa percaya diri anak, akan dapat memberikan pengaruh positif terhadap kelancaran anak dalam berbicara (Amri, 2017).

Adanya peningkatan yang signifikan antara kemampuan bahasa ekspresif (komunikasi) peserta didik sebelum diberi perlakuan (tes awal) dan setelah diberi perlakuan (tes akhir) memberikan indikasi bahwa metode bermain dapat dijadikan alternatif dalam meningkatkan perkembangan sosial dan emosional (Amri, 2017). Dengan demikian, metode bermain peran sangat mendukung interaksi sosial anak usia dini, dialog yang terjadi antar teman, imajinasi yang diaktualisasikan melalui kemampuan verbal, kemampuan anak untuk menahan diri dan mendengarkan percakapan teman akan mengantarkan anak pada rasa percaya diri dan memahami lingkungannya sedini mungkin (Nurhasanudin \& Santika, 2021).

Berbagai penelitian membuktikan bahwa metode bermain peran dapat menjadi alternatif dalam meningkatkan perkembangan sosial emosional peserta didik. Penerapan metode bermain peran dapat meningkatkan perkembangan sosial (Wintari, 2015) dan emosional peserta didik kelompok B (Shaleha et al., 2015). Metode bermain peran berpengaruh positif terhadap kemampuan bersosialisasi anak (Aida \& Rini, 2015). Terdapat pengaruh bermain peran terhadap kemampuan sosial emosional anak usia 5-6 tahun (Rabiah \& Tamba, 2014). Kemampuan sosial emosional anak dilihat dari perilaku memahami dan menaati aturan, dan sabar menunggu giliran. Kemampuan tersebut dapat ditingkatkan melalui penerapan metode bermain peran dalam proses pembelajaran (Aranda et al., 2021). Keterampilan sosial anak yang diharapkan perlahan meningkat melalui penerapan metode bermain peran. Anak lebih peduli terhadap teman, anak dapat berbagi kepada teman, anak dapat menghargai dan menghormati teman dan anak dapat memotivasi teman (Abidin, 2016).

Terdapat beberapa faktor yang dapat mendukung dan menghambat proses penerapan 
metode bermain peran untuk meningkatkan perkembangan sosial emosional anak. Beberapa faktor pendukung diantaranya adalah media, kreatifitas guru, teknik mengajar, dan antusiasme anak. Faktor pengambat diantaranya adalah egosentrisme anak, anak belum disiplin, anak cenderung pemalu (Maghfiroh et al., 2020).

\section{Kesimpulan}

Perkembangan sosial emosional peserta didik yaitu peserta didik mampu bermain peran menjadi penjual dan pembeli dengan indikator berani, percaya diri, mandiri, dan berkomunikasi telah Berkembang Sesuai Harapan (BSH). Indikator perkembangan sosial emosional yang dikembangkan melalui metode bermain peran tersebut merupakan bagian dari penguatan pendidikan karakter yang sesuai dengan nilai-nilai Pancasila.

\section{Ucapan Terima Kasih}

Tim penulis mengucapkan terima kasih kepada semua pihak yang telah membantu terlaksananya kegiatan pengabdian kepada masyarakat ini. Penulis mengucapkan terima kasih kepada: Panitia PPL Angkatan IV PPG DALJAB 2021 FKIP Universitas Mataram, Kepala Sekolah dan orang tua/wali murid TK Mustika Rini Karangnongko di Desa Karangnongko Kecamatan Nalumsari Kabupaten Jepara Provinsi Jawa Tengah.

\section{References}

Abidin, R. (2016). Peran Drama Pada Siswa Kelompok B Di TK Aisiyah Bustanul Athfal 58 Surabaya. Jurnal Pedagogi, 2, 96-106.

Aida, N., \& Rini, R. A. P. (2015). Penerapan Metode Bermain Peran untuk Meningkatkan Kemampuan Bersosialisasi Pada Pendidikan Anak Usia Dini. Persona:Jurnal Psikologi Indonesia, 4(1). https://doi.org/10.30996/persona.v4i1.494

Amri, N. A. (2017). Pengaruh Metode Bermain Peran Terhadap Kemampuan Komunikasi (Bahasa Ekspresif) Anak Taman Kanak-Kanak Raudhatul Athfal Alauddin Makassar. PEMBELAJAR: Jurnal Ilmu Pendidikan, Keguruan, Dan Pembelajaran, 1(2), 105.

https://doi.org/10.26858/pembelajar.v1i2.4864

Aranda, C. L., Levy, D. K., \& Stoney, S. (2021). Pengembangan Sosial Emosional Anak Melalui Metode Bermain Peran (Role Playing) Kelompok B Di Tk Asoka Makassar. Jurnal Edukasi Nonformal, 2(1),

154-159. https://doi.org/10.1002/9781119171386.ch15

Bakri, A. R., Nasucha, J. A., \& Indri M, D. B. (2021). Pengaruh Bermain Peran Terhadap Interaksi Sosial Anak Usia Dini. Tafkir: Interdisciplinary Journal of Islamic Education, 2(1), 58-79. https://doi.org/10.31538/tijie.v2i1.12

Dewi, kadek novia, Wirya, N., \& Ujianti, putu rahayu. (2017). Pengaruh Metode Bermain Peran Terhadap Perkembangan Sosial Emosional Pada Anak Kelompok B Di Taman Kanak-Kanak Gugus Vii Kecamatan Buleleng. E-Journal Pendidikan Anak Usia Dini Universitas Pendidikan Ganesha Jurusan Pendidikan Guru Pendidikan Anak Usia Dini, 5(3), 305-314.

Engga, Yudiernawati, A., \& Maemunah, N. (2017). Pengaruh Bermain Peran Terhadap Perkembangan Sosial Anak Usia Prasekolah (4-6 Tahun) Di Tk Tunas Bangsa Bonti Kabupaten Sanggau Kalimantan Barat. Nursing News Jurnal Ilmiah Keperawatan, 2(3), 426-436. https://publikasi.unitri.ac.id/index.php/fikes/ar ticle/view/679/540

Halifah, S. (2020). Pentingnya Bermain Peran Dalam Proses Pembelajaran Anak. JISIP (Jurnal Ilmu Sosial Dan Pendidikan), 4(3), 35-40. https://doi.org/10.36312/jisip.v4i3.1150

Jamilah, S. (2019). Pengembangan Sosial- Emosional Anak Melalui Metode Role Playing (Bermain Peran) Di Kelompok B Anak Usia Dini. PELANGI: Jurnal Pemikiran Dan Penelitian Islam Anak Usia Dini, 1(1), 83-101. https://doi.org/10.52266/pelangi.v1i1.282

Maghfiroh, A. S., Usman, J., \& Nisa, L. (2020). Penerapan Metode Bermain Peran Terhadap Perkembangan Sosial Emosional Anak Usia Dini di PAUD/KB Al-Munawwarah Pamekasan. Kiddo: Jurnal Pendidikan Islam Anak Usia Dini, 1(1), 51-65. https://doi.org/10.19105/kiddo.v1i1.2978

Mangkuwibawa, H., \& Kurnia, A. (2021). Hubungan Antara Aktivitas Bermain Peran Dengan Kecerdasan Emosional Anak. 5(02), 14-22.

Nurhasanudin, \& Santika, T. (2021). Pendekatan Sentra Bermain Peran Untuk Meningkatkan Kecerdasan Sosial Emosional Anak Usia Dini. JoCE ; Journal of Community Education, 2(1), 38-42.

Oktaviana, N. E., Elan, E., \& Mulyana, E. H. (2021). ... Kebutuhan Pengembangan Buku Panduan Bermain Peran Untuk Mengoptimalkan Perkembangan Sosial Emosional Anak Usia Dini. Jurnal Paud Agapedia, 5(1), 50-61. https:// ejournal.upi.edu/index.php/agapedia/ar ticle/view/39687

Rabiah, \& Tamba, W. (2014). Pengaruh Bermain Peran Terhadap Kemampuan Sosial Emosional Anak Usia 5-6 Tahun Di Tk Aisyiyah Bustanul Athfal 5 
Mataram. Jurnal Paedagogy, 1(1), 28-34.

Rantauwati, H. S. (2014). Pengembangan Karakter Siswa Sd Melalui Bermain Peran. Jurnal Ilmiah Guru Caraka Olah Pikir Edukatif, 0(1).

Shaleha, M., Manuaba, I. B. S., \& Putra, I. K. A. (2015). Penerapan Metode Bermain Peran Berbantuan Media Wayang untuk Meningkatkan Perkembangan Sosial Emosional Anak Kelompok B2 TK Kumara Jaya Denpasar Tahun Pelajaran 2014/2015. Jurnal Pendidikan Anak Usia Dini Undiksha, 3(1), 1-11. https://ejournal.undiksha.ac.id/index.php/JJPA UD/article/view/4970/3753

Tusyana, E., Trengginas, R., \& . S. (2019). Analisis Perkembangan Sosial-Emosional Tercapai Siswa Usia Dasar. Inventa, 3(1), 18-26. https://doi.org/10.36456/inventa.3.1.a1804

Wintari, N. L. M. (2015). Penerapan Metode Bermain Peran (Role Playing) Berbantuan Media Konkret Dalam Meningkatkan Perkembangan Sosial Emosional Anak. PG PAUD Universitas Pendidikan Ganesha, 3(1), 2. 